\title{
Hermeneutic Triangle. Ethics - Identity - Understanding
}

DOI: http://dx.doi.org/10.12775/RF.2015.005

The thesis I would like to propose is: the nature of modern and latemodern hermeneutics takes the form of a specific hermeneutic triangle, which consists of the three mentioned issues: ethics, identity and understanding. The proposal for such a hermeneutic triangle is not a methodology, although it could be re-interpreted in methodological or technical categories. It is also not about creating a formula that would provide an alternative to the hermeneutic circle which, is strongly embedded in hermeneutic tradition. The triangle neither abolishes the circle, nor brings any significant "progress" in hermeneutical reflection. I'm rather talking about a kind of strong metaphor that shows what happens in the process of understanding and self-understanding. The metaphor of a hermeneutic triangle also shows the versatility of the hermeneutic problem, which we describe under three fundamental phrases in modern humanities: the linguistic phrase (following Gadamer that understanding takes place within the horizon of what language is), the ethical phrase and the narrative phrase (identity). In other words,-contemporary humanities inevitably take a turn towards hermeneutics. 


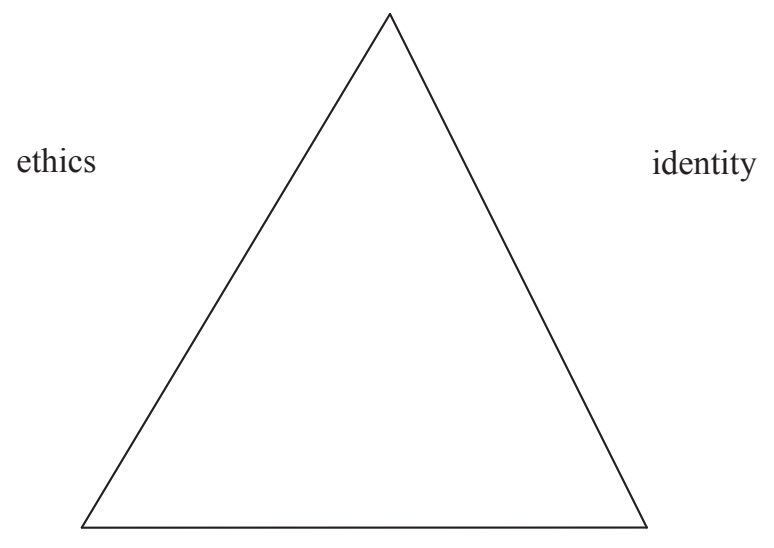

understanding

The base of the hermeneutic triangle involves understanding. Therefore, should we not reverse the order of words in the title and rather speak of understanding, ethics and identity? When it comes to the (sub) title, I accepted the philological solution known as the Behaghel's law, which states that in word clusters we should put shorter words in the first place, followed by longer ones ${ }^{1}$. Whereas from a philosophical point of view, we should distinguish understanding, which somehow embraces the other sides of the triangle and is its foundation. However, one can not indicate what comes first and what comes later here: after all, there is no causal relationship between understanding, ethics and identity. We should rather speak of the co-affiliation and structural interdependence of these three members. The concept of understanding is relational. After all, this is not a one-sided relationship in which activity is manifested only by the understanding operator, and where what is understood (another person, the world, a text) remains passive. Understanding is a dialogical situation: what is understood interrogates the understanding operator, interpreting him. Such transactional nature of understanding ${ }^{2}$, presupposing communication and dialogue, thus gains an ethical dimension. Establishing an ethical perspective allows for the removal of the fission between subject and object, which is characteristic of scientism. Hence, understanding means being face to face with Another and at the same time, self-understanding in the face of Another.

1 My attention was recently drawn to the philological Behaghel's law by Dr. Barbara Sobczak, to whom I wish to thank at this point.

2 I will write more about this in the text Reading text. On transactional interpretation. "Teksty Drugie" 1-2 (2012). 
In this sense, however, we are now entering the dimension of identity. Who am I in the face of Another? Who is the one who understands? What is going on in the course of understanding? Who/what is understood? However, the question understood about identity, about who I am and who you are, is not imposed as a consequence of the previously established ethical perspective, but rather it belongs to it. After all, I cannot ask about my identity without understandingly referring to Another and vice versa. In this way, the isolation or atomization of what is individual is broken. The "I" illuminates (and at the same time becomes obscure) only in the "You" perspective.

But let us return to the problem of understanding. The notion of understanding as the base of the hermeneutic triangle is inevitably entangled in the context of Heidegger onto-hermeneutics. Thus, understanding is not a procedure, method or tool that we can always put away. Understanding is rather seen as the nature of human existence. This is because what characterizes being-in-the-world Dasein is that Dasein always refers to one's being.

In Being and Time, a critical work in modern hermeneutics, Heidegger emphasized the timing nature of human understanding. Beingin-the-world is determined by the reality (projection), falling down and the project, which correspond to the being (past), modernizing (present) and the future. Understanding is therefore always positioned, projected, determined by what is past. This means that there is no zero level of understanding, no starting point where understanding begins. This does not mean, however, that understanding is always predetermined by what was in the past. Nor is it a fact that the location of understanding should first be removed to clear the field for an understanding that is transparent, untainted, unconditioned, or "proper". If that were the case, we would have to go back to an abstract epistemic operator. On the contrary, reality is a positive condition of all understanding, which can only take the form of a project, a coating for the future possibilities of being. Heidegger calls such a future-oriented direction of understanding right or authentic. As Andrzej Przyłębski states: "Projection enables us new ways of understanding beings, thus opening up new ways for self-realization, and allows that being new ways of self-presentation" ${ }^{\prime 3}$. Whereas being-in-the-world Dasein plunged in what is present, the everyday bustle and forethought, turns out to be the "Self" domain in the inauthentic life (understanding). It is known that Heidegger does not approach the ethical dimension in the sense of duty. Non-proper understanding is not something negative, pejorative; on the contrary, it has a positive meaning, because it belongs to the very being. Heidegger actually emphasizes that this non-proper understanding can be thoroughly

\footnotetext{
3 A. Przyłębski, Etyka w świetle hermeneutyki, Warszawa 2010, pp. 58-59.
} 
authentic, while what is commonly referred to as authenticity ("extravagant tinkering with the soul") "can be extremely inauthentic or even pathological"

This non-proper understanding is not coming from the world that surrounds us, or the world, to which we are committed, or from the issues we are concerned about daily. According to Heidegger, it is about understanding oneself in terms of things, utility connections, that is useful. In this sense, we never meet others directly - they are mediated indirectly by tools. In this sense, too: I myself am mediated for myself by the things that consume me. The opacity of the "I" and "others" makes "being-with-each-other" non-proper (inauthentic). The identity of the "I" appears appropriately for determination. "Selfness" - freedom and openness to the other "You" can only be given on the basis of individualization. This happens when I realize that I belong to myself and that the being who is me is always mine $e^{5}$ Only then it becomes clear that identity as selfness (Selbstheit) results in a person being able to live nonproperly (forgetting about oneself, losing oneself, being defined by others - anonymous "Self"), or properly (by choosing oneself). Nevertheless, one must keep in mind that proper (authentic) life/understanding is not a negation or ethical transformation of non-proper (inauthentic) life, but a sort of its modification ${ }^{6}$. Raising the issue of selfness consequently implies the problem of correct being-with-each-other: it takes place when at first I care about myself. Only then it becomes possible to become free and open to the other "I".

As we know, Heidegger's ontological concept of understanding has not translated into ethics, although it is hard not to notice the possible ethical implications in this way of thinking ${ }^{7}$. Humans are drawn towards an authentic existence by fear. It is also difficult to refrain from ethical interpretations of the phenomena of decision (choice), freedom, guilt or conscience. Doubts are always raised by Heidegger's considerations which were unable to apprehend the existence of the Other/Others and therefore, question the possibility of raising ethics ${ }^{8}$. On the other hand,

${ }_{4}$ M. Heidegger, Podstawowe problemy fenomenologii, trans. B. Baran, Warszawa 2009, p. 174.

5 Ibidem, p. 184.

6 Ibidem, p. 185.

7 These issues are discussed superbly by Andrzej Przyłębski (Etyka w świetle hermeneutyki..., op.cit.); we also know the ethical implications of Heidegger's thought in Sartre's existentialism - see his Being and Nothingness, transl. J. Kiełbasa, P. Mróz et al., Kraków 2007; in this case, see also K. Sipowicz, Heidegger: degeneracja i nieautentyczność. Warszawa 2005.

8 See e.g. A. Przyłębski, Etyka..., op.cit.; M. Buber, I and Thou, transl. J. Doktór. Warszawa 1992; H. G. Gadamer, A Century of Philosophy. Convensartion with Riccardo Dottori. transl. J. Wilk, Wrocław 2009. 
it seems to me that the onto-hermeneutics of the author of Being and Time can reasonably be interpreted on the basis of what Charles Taylor has described as the ethics of authenticity, derived from the late eighteenth century. Its characteristic dimension, already present e.g. in Rousseau or Herder, and now found in Heidegger is based on the individualistic moral ideal of authenticity, in which freedom, responsibility, or guilt relate primarily to the "selfness" of an individual". To put it in a nutshell: regardless of doubts that may be raised by Heidegger's project, as well as contrary to his claims, we may recognize that the ontological analysis of understanding as the highlighted way of human existence can be the starting point for ethical interpretation.

There is no doubt as to the fact that the existential analysis of Dasein determines the original way of thinking about the modern category of narrative identity. As was rightly pointed out by Katarzyna Rosner:

"Heidegger's timing understanding is a process close in structure to the narrative (...). After all, this understanding is primarily self-understanding; past events - involving the past life of a person, their decisions, plans, the person's actions and their consequences; future design - plans for future activities and defining their goals in light of the opportunities that the past presents. At any time of self-narration, the person designs their own future - themselves, in light of what already is, and their current situation. Self-understanding or auto-narrative - both according to Heidegger and narrativists - are not passive processes; in both approaches, it involves the design and constitution of oneself, of one's identity. (...) The key assumption for narrativists that the identity of an individual is not given, but is constructed in the process of self-understanding, derives from Heidegger's analysis. More important, however, is the fact that this assumption is only possible on the basis of ontology of a being rejecting its object structure and declaring temporality as a constitutive ontological feature of human existence" ${ }^{\prime 10}$.

To sum up this thread, we can reasonably conclude that one can deduce what I metaphorically call the triangle hermeneutic from Heiddeger's analysis of being-in-the-world as understanding. It turns out, however, that this hermeneutic triangle is also found in the hermeneutics of Hans-Georg Gadamer and Paul Ricoeur.

How does it look according to Gadamer? At this point I would like to pass over the questions posed by the author of Truth and Method, concerning the possibility of philosophical ethics ${ }^{11}$. This issue was well-

9 Also see Ch. Taylor, The Ethics of Authenticity, transl. A. Pawelec, Kraków 2002.

10 K. Rosner, Narracja, tożsamość i czas, Kraków 2006, pp. 22-23.

11 H. G. Gadamer, O możliwościach etyki filozoficznej, trans. A. Mergler. In Teoria, etyka, edukacja. Eseje wybrane. R. Godoń (select.), P. Dybel (ed). Var. transl. Warszawa 2008. 
discussed by Andrzej Przyłębski ${ }^{12}$. Meanwhile, I would like to briefly refer to the direct link between understanding/interpretation, ethics and identity. The mere raising of the problem as to what dialogue is, regarding understanding and interpretation, implies ethical issues. Gadamer restores text previously understood by Plato as what is dead, "a ghost of speech," into the area of live discourse. The text thus becomes Another-interlocutor, which calls for respect: hearing. Gadamer therefore breaks away from the epistemological approach, consisting in the appropriation of Another. Among other reasons, this is why he also rejects the method which, in his opinion, is no privileged way to the truth. Yet this does not mean that the truth is questioned. On the contrary, the truth (of text) turns out to be an ethical and hermeneutical requirement that the interpreter confronts as "the arbiter of its claim to truth"13. As we know, Gadamer treats each statement as an answer to a question. It is the ethical duty of the interpreter to reach this question, which is carried out with the attitude of "trusting" the text, but also anticipating the meaning of the text as a whole on the basis of pre-judgments. However, comprehension as tradition and cultural transmission, is possible through applying text understanding the situation of the understanding person, their experience, values, ideas etc. In other words: as subtilitas applicandi, interpretation always involves contextualization by the interpreter. But how does one contextualise? What interpretative conclusions or decisions does one make? Where does one find the rules? The problem is that understanding appears to be an issue of neither knowledge understood as sophia (theoretical knowledge detached from experience), nor techne type of knowledge (which determines and directs the modus operandi), but rather phronesis, practical knowledge embedded in one's experience, knowledge and morals. Moral knowledge is different from techne: the validity of one's behaviour is not a matter of a priori knowledge, which can be used, but the knowledge inherent in our upbringing, habits, experiences, and which cannot be separated from our situation. Humanities (as hermeneutics) therefore become closely linked to moral knowledge. As Gadamer says:

"But we do not learn moral knowledge, nor can we forget it. (...) Rather, we are always already in the situation of having to act (...), and hence we must already possess and be able to apply moral knowledge. That is why the concept of application is highly problematical. For we can only apply something that we already have; but we do not possess moral knowledge in such a way that we already have it and then apply it to specific situations. The image that a man has of what he ought to be - i.e.

12 A. Przyłębski, Gadamera kłopoty z etyką. In Etyka..., op.cit.

13 H. G. Gadamer, Truth and Method, transl. J. Weinsheimer, D. G. Marshall. London-New York 2004, p. 396. 
his ideas of right and wrong, of decency, courage, dignity, loyalty, and so forth (all concepts that have their equivalents in Aristotle's catalogue of virtues) - are certainly in some sense images that he uses to guide his conduct. But there is still a basic difference between this and the guiding image the craftsman uses: the plan of the object he is going to make. What is right, for example, cannot be fully determined independently of the situation that requires a right action from me, whereas the eidos of what a craftsman wants to make is fully determined by the use for which it is intended"14.

At this point, phronesis as moral knowledge also brings about the issue of identity. Humanities belong to the moral teachings and sciences. "Their object is man and what he knows of himself"15. By making situational and ethical decisions full of uncertainty and anxiety, each time we hear the question of our identity: Who are we? What are we? What do we know about ourselves? Are we free enough? Are we responsible enough?

An unbreakable bond between understanding, identity and ethics can be clearly found in the works of Paul Ricoeur. To understand oneself means to understand oneself in the face of another (where another is not only another person, but also a text) ${ }^{16}$. Understanding is always already mediated: through history, symbols, metaphors, in short - by language mediation. If so, the issue of identity has nothing to do with the Cartesian, self-reassured subject. In his "dense" and subtle analyses, Ricoeur gives an account of the ambivalence of identity, which is marked by the clash between identitas (idem) and ipseitas (ipse) ${ }^{17}$. A human being does not fall within the identitas, which is primarily characterized by the way things exist. A cauliflower or a chair is what it is. A chair, for example, is a useful object; one can bring it down completely to the function it performs. In older literature, it often happened that a person would be clearly reduced to some function or trait of character; the characters were given unambiguous names (Tartuffe, Hotspur). In fact, however, the human

14 H. G. Gadamer, Truth and Method, transl. J. Weinsheimer, D. G. Marshall. London-New York 2004, p. 315.

15 Ibidem, p. 312.

16 See A. Wierciński, Hermeneutics and the Indirect Path to Underststanding. In The Task of Interpretation: Hermeneutics, Psychoanalysis, and Literary Studies. D. Skórczewski, A. Wierciński, E. Fiała (eds.), Lublin 2009; A. Wierciński, Celebrating the Confusion of Voices and the Fusion of Hermeneutics Horizons. In Between Suspicion and Sympathy. Paul Ricoeur's Unstable Equilibrium. A. Wierciński (ed.), Toronto 2003.

17 Reflection in a similar manner was taken much earlier (1943), although in different terms, Jean-Paul Sartre, by confronting being-in-oneself and being-for-oneself. Being-in-oneself is characterized as a being that ",is what it is". Whereas a human being (being-for-oneself) „,is what it isn't and is not what it is". See Jean-Paul Sartre, Byt i nicość..., op. cit. 
identity is ipseitas, devoid of immutable essence. Human "selfness" is what is In statu nascendi; it is shaped and changes over time and through the course of one's conduct and actions ${ }^{18}$. In this sense "selfness" also proves to be a function of the narrative, the stories that we constantly construct, deconstruct and reconstruct regarding ourselves, but also the world and other people ${ }^{19}$. We ourselves are narrated by others, which makes us constantly adjust and revise our own stories. It can be said that Ricoeur's thinking clearly resonates with Rimbaud's notion, stating that "I is someone else". "I" is someone else to oneself, to my idem (e.g. body, a portrait on one's old photograph). But " $\mathrm{I}$ " is also someone else against another person, another who is calling me, ethically obliging, and through whom I become someone else. As Małgorzata Kowalska accurately noted while interpreting Ricoeur:

"No one is themselves in a social, historical and moral vacuum. The sense of individual existence is determined by relations (both experiencing and acting) that connect the individual subject with others - not just a specific "you"; with the other as "another", but also with an anonymous "third", with "everyone", and not only with those currently living, but also with our ancestors and children. (...) the entity considered in the context of relationships is, above all, a moral entity as well" ${ }^{20}$

The issues I refer to became the subject of extensive and in-depth analysis and interpretation, which is found on the basis of existential hermeneutics. I bring them up in the most general and simplified manner, only to highlight what, in my opinion, has not been clearly named: as the unity of the "triangle" where understanding, identity and ethics appear to be the main areas of interest of existential hermeneutics, with very important implications (such as temporality and narrative).

Hermeneutics is not a method or even an idea for reading texts. Nor is it simply a specialty, subject to expert knowledge or a discipline. It is much more: a comprehensive manner of being, whose character is determined by constantly renewed attempts to understand the world into which we were thrown, and which we must somehow tame. Hermeneutics is an attempt to understand what actually happens. It is a constant attempt to make conversation, in which the last word is never really told. After all, even though the purpose of dialogue seems to be communication, this Another entity (person, text, the world) would never be completely understood: Individuum est ineffabile. A human being lost

18 See P. Ricoeur, O sobie samym jako innym, trans. B. Chełstowski, Warszawa 2003.

19 See ibidem, Czas i opowieść. Var. trans. Kraków 2008, t. 1-3.

20 M. Kowalska, Dialektyka bycia soba (Ricoeura filozofia podmiotu). In Horyzonty interpretacji. Wokót myśli Paula Ricoeura, A. Grzegorczyk, M. Loba, R. Koschany (eds.). Poznań 2003, p. 128. 
in the phronimos, still follows their own way, trying to read the blurred signs; deprived of guidance and rules, left with only their own imperfect experience, day after day chasing a sense that keeps escaping and falls apart like a house of cards. Hermeneutics does not stop at this point, but it is a repeated Sisyphean work of constructing the unconstructable; it is an affirmation of the impossible, the knowledge that each of us was called to pass through Kafka's Gate of Law.

\section{Bibliography}

Buber M., Ja i Ty, transl. J. Doktór. Warszawa 1992.

Gadamer H.-G., Wiek filozofii. Rozmowy z Riccardo Dottori. transl. J. Wilk, Wrocław 2009.

Gadamer H.-G.,Teoria, etyka, edukacja. Eseje wybrane. Selection R. Godoń. Edit. P. Dybel. Var. transl. Warszawa 2008.

Gadamer H.-G., Truth and Method, transl. J. Weinsheimer , D. G. Marshall. London-New York 2004.

Heidegger M., Podstawowe problemy fenomenologii, transl. B. Baran. Warszawa 2009.

Horyzonty interpretacji. Wokót myśli Paula Ricoeura. A. Grzegorczyk, M. Loba, R. Koschany (eds.), Poznań 2003.

Januszkiewicz M., Wczytywanie (się) w tekst. O interpretacji transakcyjnej. „Teksty Drugie" 2012, no. 1-2.

Przyłębski A., Etyka w świetle hermeneutyki. Warszawa 2010.

Ricoeur P., O sobie samym jako innym. Tłum. B. Chełstowski. Warszawa 2003. Ricoeur P.,Czas i opowieść. Var. trans. Kraków 2008, t. 1-3.

Rosner K., Narracja, tożsamość i czas. Kraków 2006.

Sartre J.-P., Byt i nicość, transl. J. Kiełbasa, P. Mróz i in. Kraków 2007.

Taylor C., Etyka autentyczności. Transl. A. Pawelec. Kraków 2002.

Wierciński (ed.), Between Suspicion and Sympathy. Paul Ricoeur's Unstable Equilibrium, Toronto 2003.

Wierciński A., Hermeneutics and the Indirect Path to Underststanding. In The Task of Interpretation: Hermeneutics, Psychoanalysis, and Literary Studies, D. Skórczewski, A. Wierciński, E. Fiała (eds.), Lublin 2009.

\section{Summary}

The thesis I would like to propose is: the nature of modern and late-modern hermeneutics takes the form of a specific hermeneutic triangle, which consists of the three mentioned issues: ethics, identity and understanding. The proposal for such a hermeneutic triangle is not a methodology, although it could be reinterpreted in methodological or technical categories. It is also not about creating a formula that would provide an alternative to the hermeneutic circle, which is strongly embedded in hermeneutic tradition. The triangle neither abolishes the circle, nor brings any significant "progress" in hermeneutical reflection. I'm 
rather talking about a kind of strong metaphor that shows what happens in the process of understanding and self-understanding. The metaphor of a hermeneutic triangle also shows the versatility of the hermeneutic problem, which we describe under three fundamental phrases in modern humanities: the linguistic phrase (following Gadamer that understanding takes place within the horizon of what language is), the ethical phrase and narrative phrase (identity). In other words, contemporary humanities inevitably take a turn towards hermeneutics.

\section{Keywords}

hermeneutics, understanding, identity, ethics 